\title{
RETRACTED ARTICLE: Genotoxicity and alteration of the Gene Regulatory Network expression during Paracentrotus lividus development in the presence of carbon nanoparticles
}

\author{
Elisabetta Carata ${ }^{1}$ (D) $\cdot$ Bernardetta Anna Tenuzzo $^{1} \cdot$ Stefania Mariano $^{1}$ (D) Andrea Setini ${ }^{2}$ (D) $\cdot$ Marco Fidaleo $^{2}$ (D) . \\ Luciana Dini ${ }^{2,3}$ (D)
}

Received: 1 September 2020 / Revised: 13 November 2020 / Accepted: 17 December 2020 / Published online: 12 April 2021

(c) The Author(s) 2021

The Editor-in-Chief has retracted this article. After publication, two of the panels in Figure 1C were found to overlap with figures in another published article [1], specifically: Figure 1C left panel overlaps with Figure 2A of [1]. Figure $1 \mathrm{C}$ middle panel overlaps with Figure 6 of [1]. The Editor-in-Chief therefore no longer has confidence in the integrity of the data in this article. The authors have agreed to this retraction but not to the wording of this retraction notice. [1] Manno D, Serra A, Buccolieri A, Panzarini E, Carata E, Tenuzzo B, Izzo D, Vergallo C, Rossi M, Dini L (2013) Silver and carbon nanoparticles toxicity in sea urchin Paracentrotus lividus embryos. BioNanoMat 14(3-4):229-238.
Supplementary Information The online version contains supplementary material available at https://doi.org/10.1007/s43188-020-00081-y.

Open Access This article is licensed under a Creative Commons Attribution 4.0 International License, which permits use, sharing, adaptation, distribution and reproduction in any medium or format, as long as you give appropriate credit to the original author(s) and the source, provide a link to the Creative Commons licence, and indicate if changes were made. The images or other third party material in this article are included in the article's Creative Commons licence, unless indicated otherwise in a credit line to the material. If material is not included in the article's Creative Commons licence and your intended use is not permitted by statutory regulation or exceeds the permitted use, you will need to obtain permission directly from the copyright holder. To view a copy of this licence, visit http://creativecommons.org/licenses/by/4.0/.

Luciana Dini

luciana.dini@uniroma1.it

1 Department of Biological and Environmental Science and Technology, Di.S.Te.B.A. University of Salento, Lecce, Italy

2 Department of Biology and Biotechnology "C. Darwin", Sapienza University of Rome, Rome, Italy

3 CNR-Nanotec, Lecce, Italy 